\title{
Article \\ Intrapreneurial Fit and Misfit: Enterprising Behavior, Preferred Organizational and Open Innovation Culture
}

\author{
Nick Chandler * (D) and Zoltán Krajcsák \\ Department of Management, Budapest Business School, 1149 Budapest, Hungary; krajcsak.zoltan@uni-bge.hu \\ * Correspondence: chandler.nicholas@uni-bge.hu
}

check for

updates

Citation: Chandler, N.; Krajcsák, Z Intrapreneurial Fit and Misfit: Enterprising Behavior, Preferred Organizational and Open Innovation Culture. J. Open Innov. Technol. Mark. Complex. 2021, 7, 61. https://doi.org/ 10.3390/joitmc7010061

Received: 12 January 2021

Accepted: 4 February 2021

Published: 8 February 202

Publisher's Note: MDPI stays neutra with regard to jurisdictional claims in published maps and institutional affiliations.

Copyright: (c) 2021 by the authors. Licensee MDPI, Basel, Switzerland. This article is an open access article distributed under the terms and conditions of the Creative Commons Attribution (CC BY) license (https:/ / creativecommons.org/licenses/by/ $4.0 /)$.

\begin{abstract}
In challenging times, the need for innovation is heightened and stems from employees who exhibit intrapreneurial characteristics. Not every corporate culture is a suitable environment for intrapreneurial behavior. This study examines the relationship between potential entrepreneurial behavior and preferred culture type. Through a principal component analysis of a sample of 1056 university students, four principal components of enterprising behavior (and roles) are found: Planning on results (project manager); Bearing the burden (pressure bearer); Innovating for others (innovating showstopper); and Learning from mistakes (experimental learner). Using the Organizational Culture Assessment Instrument, a linear regression analysis was conducted of culture types against components. A combination of strong inverse and direct relationships are found between these components and culture types (clan, market, adhocracy, and hierarchy). The findings help practitioners understand how existing culture will inhibit or encourage enterprising behaviors, with potential benefits in recruitment and selection, reductions in staff turnover and increases in innovation potential. The findings also indicate a need for reconsideration of the employer brand when attracting intrapreneurs.
\end{abstract}

Keywords: fit; organizational culture; intrapreneur; characteristics

\section{Introduction}

Innovation in companies serves as a means for overcoming challenges and keeping pace with rapid technological change [1]. The source of innovation for many companies stems from their pool of professionals that have an intrapreneurial profile [2], i.e., exhibit enterprising behaviors. If intrapreneurial activities are to flourish in organizations, then favorable internal conditions are an absolute necessity [3]. However, not every organizational culture is the right internal environment for intrapreneurship to flourish [4]. Whilst some organizations and studies advocate the building of or transformation into an entrepreneurial culture to encourage employees' enterprising behavior [5], not all organizations have the resources for this transformation. In these cases, organizations need to consider how future and current employees' enterprising behaviors may fit the existing organizational culture. From this perspective, person-organization fit highlights the need for effective selection processes as a meaning of ensuring retention of "enterprising employees", particularly as research has indicated that the fit between an organization's culture and new employees' value preferences is a predictor of turnover [6,7].

Authors [8] reviewed current research and found that 'the concept of entrepreneurship has evolved from launching a new business to any entrepreneurial activities that involve a new way to operate a business or NGO, or an existing organization'. The need for intrapreneurial traits and behaviors extends to many areas of organizations and has become a strategic issue for ensuring the performance of organizations [9] as employees need to adopt intrapreneurial roles, such as innovators and differentiators [10]. The identification and encouragement of intrapreneurial characteristics thus requires not only an understanding and overview of the labor market, but also a consideration for their compatibility with the corporate culture [11]. 
The authors [12] stressed the need for a change of focus in the corporate world from new product development and process innovation towards the mindset of the intrapreneurial people who drive change. Recent literature on intrapreneurial characteristics has focused on encouraging employees to become more intrapreneurial (e.g., [13]) and consider the associated beneficial effects of this, such as commitment [14]. The authors [9] (p. 564) highlight the current research gap in this field: 'there is a gap between our knowledge about intrapreneurial employees and intrapreneurship within specific functions and context'. Ref. [9]'s proposed future research directions include the need for an assessment of intrapreneurial characteristics on an individual level. From a cultural perspective, [15] concluded there is a great need for studies into culture and entrepreneurial themes. Since this study, the majority of research has focused on culture change and achieving an entrepreneurial culture (e.g., [16,17]), or on national culture and entrepreneurship (e.g., [18]), despite [19] warning that, whilst national culture has an important role in the context of intrapreneurship, other levels of culture should not be neglected. Moreover, [20] emphasize the need for research into the link between entrepreneurial characteristics and culture.

The research question of this study is: what is the relationship between intrapreneurial characteristics and preferred organizational culture? Through answering this research question, this study seeks to ascertain exactly which intrapreneurial characteristics fit which types of organizational culture, should there be a relationship between these two elements. Knowing the results, it is possible to identify the key behaviors that are particularly supported or opposed within a workplace's organizational culture, and the development of these "culture-fitting behaviors" can be started in a targeted way during the orientation of new employees.

\section{Theoretical Underpinnings}

To consider what constitutes intrapreneurial characteristics, we first consider the operational definitions of this study with respect to both entrepreneurs and intrapreneurs. There is debate concerning an exact definition of the term "entrepreneur' [21]. The authors [22] defined entrepreneurship as a person who creates value by taking financial, social, and physical risks in exchange for monetary rewards and satisfaction. Researchers [23] also define an entrepreneur as a person undertaking risks but also one who has the necessary ability to launch new projects. In [24], the authors also highlight the need to convert resources into values but highlight how an essential set of characteristics are required for an entrepreneur to be able to convert resources into value. It is these characteristics that form the focus of this study. In [25], the authors define the entrepreneur as 'a person who habitually creates and innovates to build something of recognized value around perceived opportunities.' In contrast, [26] defines the entrepreneur as 'a motivated individual who makes decisions on funding in emerging businesses'; knowing that business value is the outcome of many interacting factors that are still under study and scrutiny by researchers [27].

As [28] indicates, not everyone who has entrepreneurial characteristics is destined to be an entrepreneur, but rather "an enterprising person". This is an important distinction as this study is not concerned with the potential of individuals to become entrepreneurs (see [29]), but rather the enterprising behavior that may be useful for organizations looking to develop and rely on intrapreneurial behavior. In [28], the researcher defines the intrapreneur as an enterprising person who supports new initiatives in established organizations and 'makes some material difference', not only coming up with new and valuable ideas but ideas which they themselves are able to resource and develop. This view is echoed by [2], who say that the intrapreneur is 'a professional who, from an idea and with enough internal decision-power, encourages resource allocation and devotes him/herself enthusiastically to turn that idea into a successful product or service' (p. 838).

Intrapreneurship is internal corporate entrepreneurship that drives operational flexibility for a company [30]. Thus, although it is conceded that there are differences between an entrepreneur and intrapreneur, for the purposes of this study the intrapreneur is con- 
sidered an enterprising person that has a number of entrepreneurial characteristics, and hereafter, references to entrepreneurship relate to the enterprising persons at the focus of this study. This definition of an entrepreneur is somewhat broad and indicates a change of perception from an economic activity, towards characteristics relevant to everybody and 'an entrepreneurial mindset' [31]. Whilst the cognitive underpinnings of entrepreneurial activity may aid in developing entrepreneurial characteristics in enterprising persons (see for example [32]), these cognitive processes are beyond the scope of this study.

Early works in this field examined entrepreneurship based upon traits relating to specific activities, such as: risk taking [33], innovativeness, achievement orientation and dominance [34] and knowledge and entrepreneurial discovery [35]. The trait approach to entrepreneurship was introduced by [36] and has been used for many studies into entrepreneurial characteristics (e.g., [21]). An assumption behind this approach is that entrepreneurs are a certain type that can be distinguished from other groups of individuals [37]. However, the trait approach is criticized, as studies employ different definitions of entrepreneur [38], potentially leading to differences in trait sets. The trait approach has also come under criticism for assuming people behave consistently in different situations [39]. For this study, we are not concerned with the traits that constitute an entrepreneur per se, but the link between enterprising behaviors and preferred culture (values). Values that constitute an individual's preferred organizational culture are reflected in [40] defining a value as 'an enduring belief that a specific mode of conduct or end-state of existence is personally or socially preferable to an opposite or converse mode of conduct or end-state of existence'. The study also adopts a cultural perspective of the entrepreneurial behaviors and, as [41] showed, there is consistency among behaviors to the extent that behaviors can be anticipated and predicted based upon individual affiliations (or a lack thereof) to a particular culture.

\section{Entrepreneurial Characteristics}

Beyond the earliest works examining entrepreneurial traits, [42] looked at psychological characteristics in an intrapreneurial context. Since then, studies in this field have evolved in a variety of directions. Authors [2] highlight that research into entrepreneurship has covered three levels of analysis over the last decade: the individual level, the organizational level and the macro level. Many of the studies into entrepreneurial characteristics in general, and entrepreneurial orientation (EO) in particular, have been at the organizational level (e.g., [42-44]). There is some debate on the level of analysis for EO. Some studies argue EO relates to a strategic orientation and therefore is suited solely to firm level $[45,46]$. Other studies link individual and organizational levels of entrepreneurship research through management theory [47] and have coined the term "individual entrepreneurship orientation" (IEO), which has been used in studies of senior management in organizations [48]. This study will refer to entrepreneurial characteristics as enterprising behavior, but will avoid the term "entrepreneurial orientation", due to its association with either firm-level analysis or solely senior management, neither of which is within the scope of this study.

The formative review of [49] of entrepreneurial characteristics identified fourteen characteristics of successful entrepreneurs, and yet, they could not find a single entrepreneur with a high degree of all fourteen characteristics. Since this time, many empirical studies have identified a range of characteristics. The following table gives an overview of the characteristics examined in empirical studies and as indicated, studies often focus on skill sets, capabilities, personality traits and other characteristics, or a combination of all of these. This is the reason elements are grouped in this study under the umbrella of "characteristics" (Table 1). 
Table 1. Enterprising characteristics in empirical studies.

\begin{tabular}{|c|c|}
\hline Author & Characteristics \\
\hline [50] & $\begin{array}{l}\text { High need for achievement, internal locus of control, moderate risk-taking orientation, } \\
\text { high tolerance for ambiguity, high degree of self-confidence and innovativeness. }\end{array}$ \\
\hline [51] & $\begin{array}{l}\text { the need for achievement (work ethic), pursuit of excellence, mastery, dominance) and } \\
\text { locus of control (chance, internal, powerful others). }\end{array}$ \\
\hline [52] & $\begin{array}{l}\text { "Focus" (target focus, time focus and action focus), "Advantage" (opportunity } \\
\text { selection, benefit orientation, performance orientation, resourcing, and vision), } \\
\text { "Creativity", "Inner Ego" (self-assurance, dedication, and motivation), "Outer Ego" } \\
\text { (responsibility, accountability, and courage), "Team" (ability to select the right people } \\
\text { for your team, creating the right environment to encourage teamwork, knowing when } \\
\text { to look for expertise outside the team, and networking), "Social" ability. }\end{array}$ \\
\hline [53] & $\begin{array}{l}\text { Commitment and determination, leadership, opportunity obsession, taking initiative } \\
\text { and personal responsibility, tolerance of risk, ambiguity and uncertainty, motivation } \\
\text { to excel. }\end{array}$ \\
\hline [54] & $\begin{array}{l}\text { Locus of control, need for achievement, tolerance for ambiguity, risk taking, } \\
\text { self-confidence and innovativeness. }\end{array}$ \\
\hline [55] & $\begin{array}{l}\text { Need for achievement, risk-taking, innovativeness, autonomy, locus of control } \\
\text { and self-efficacy. }\end{array}$ \\
\hline [56] & Inner control, planning and goal setting, risk taking, innovation. \\
\hline [57] & $\begin{array}{l}\text { Planning and perseverance, persuasion and networking, communication ability, } \\
\text { commitment, overcoming failure, self-confidence and locus of control, risk-taking } \\
\text { ability, initiative and responsibility, high energy level, tolerance for ambiguity and } \\
\text { uncertainty, creativity and flexibility, knowledge-seeking, continuous learning, } \\
\text { financial proficiency, money sense, business knowledge. }\end{array}$ \\
\hline [58] & $\begin{array}{l}\text { Entrepreneurial skills: seeking new market opportunities, identifying goods and } \\
\text { services that people want, exploiting high quality market. opportunities, having } \\
\text { special sensitivity toward market opportunities, identifying market opportunities that } \\
\text { are better than others. } \\
\text { Managerial capabilities: achieving results by organizing and motivating people, or } \\
\text { organizing resources and coordinating tasks, being able to delegate effectively, being } \\
\text { able to supervise, influencing and leading people. }\end{array}$ \\
\hline [59] & Innovativeness, proactiveness, risk-taking and market-sensing capability. \\
\hline$[60]$ & $\begin{array}{l}\text { Dynamic capabilities (e.g., learning capability, ability to respond), innovation, } \\
\text { proactiveness, risk taking, and social aspects linked to 'relational resources' (e.g., } \\
\text { strength and closeness of relationships). }\end{array}$ \\
\hline
\end{tabular}

As mentioned in the theoretical underpinnings section, it can be seen in the table that the characteristics vary across studies and are often linked to the definition of entrepreneur used in the study. In the final row of the table, [60] include a number of 'relational resources'. Although these might not specify entrepreneurial traits in themselves in the study, it can be assumed that having strong and close relationships with customers necessitates a certain degree of social capability.

\section{Linking Organizational Culture and Entrepreneurial Characteristics}

Organizational culture is 'a pattern of basic assumptions that a group has invented, discovered or developed in learning to cope with its problems of external adaptation and internal integration, and that have worked well enough to be considered valid, and therefore, to be taught to new members as the correct way to perceive, think, and feel in relation to those problems' ([61], p. 111). Many of these assumptions are expressed in the form of attitudes, behavior, feelings, relationships, language, physical settings, symbolism and artefacts, and this also applies to innovation cultures in organizations [62]. Authors [63] confirm that entrepreneurial characteristics (behaviors, attitudes, etc.) are shaped by values, as the desirability of risk-taking and independent thinking vary across national cultures. 
Empirical evidence was found by [20] of national differences between national culture and entrepreneurial orientation. Much of the research into the link between entrepreneurialism and cultural fit has taken place on a national level (e.g., [64,65]), or the organizational level with a national context [20] but there is a scarcity of studies linking organizational culture on an individual level (i.e., individual values relating to specific culture types) to entrepreneurial characteristics.

Authors [66] suggest that the socio-cultural background of an individual acts as a stimulator and/or motivator of entrepreneurial behaviors. Other authors [3] also confirm that the internal dimensions of an organization deeply affect entrepreneurial behaviors, such as innovation. Studies have indicated that entrepreneurial and innovating behaviors (both individual and firm level) are dependent on cultural factors (e.g., $[67,68])$. Some authors [69] suggest that organizational culture could be an antecedent of entrepreneurial behavior in SMEs, or more specifically, organizational climate and management practices may be the key antecedents to an entrepreneurial orientation [68].

The issue of entrepreneurs fitting into particular cultures has been cited as a possible reason for why entrepreneurially oriented firms are more successful in some countries but not others [70]. The need for alignment, also called the fit paradigm, requires congruity between managerial practice and the culture, be it on a national or organizational level (see [63,71]). Conversely, a lack of fit has been found to inhibit entrepreneurial activities [72]. Although little research has been undertaken on the organizational level, the role of managers in both developing the values relating to organizational culture and encouraging or discouraging the enterprising behavior of employees has been found in the qualitative study of [73]. Further evidence of the link between culture and entrepreneurship is seen in studies that found education influences values and level of entrepreneurship [63,74]. Moreover, education and knowledge have been found by [75] to have key roles in turning a "Technology-Based Firm" into a "Technology-Based and Highly Innovative Firm".

\section{Methodology}

The main aim of this study is to investigate the relationship between enterprising behavior and preferred culture type (values). The following methodology was employed to achieve this aim.

\subsection{Choice of Sample}

As found in the literature, as soon as an employee begins work, organizational values begin to be passed on to the new employee [61]. Thus, any study of the link between values and enterprising behavior needs to eliminate the influence of organizational culture, especially as fit begins through adaptation to the culture from day one of employment. The choice of sample, therefore, involves people without work experience, namely those from a University.

A convenience sampling method was used in which the questionnaires were completed by 1056 undergraduate students at selected tertiary institutions in Hungary. According to the most recent data available concerning Hungary from the Global Entrepreneurship Monitor [76], Hungary's level of entrepreneurial activity is lower than the regional and global averages.

For the composition of the sample (Table 2), distribution between male and female respondents was 37.9 per cent and 62.1 per cent, respectively. Most (97.1 per cent) of the respondents were younger than 23 years old. Any students that had previous work experience or had their own business were excluded from the study. 
Table 2. Distribution of sample by course studied.

\begin{tabular}{cccc}
\hline Institution & Course & Frequency & Percent \\
\hline 1 & Human Resources & 65 & 6.2 \\
& IT for Business & 42 & 4 \\
& Business Management & 38 & 3.6 \\
& Finance and Accounting & 246 & 23.3 \\
2 & International Economics & 71 & 6.7 \\
& International Management & 149 & 14.1 \\
& International Studies & 168 & 15.9 \\
& Logistics & 14 & 1.3 \\
3 & Marketing & 140 & 13.3 \\
& Tourism & 123 & 11.6 \\
& Total & 1056 & 100.0 \\
\hline
\end{tabular}

There have been a number of studies using this type of sample to examine aspects of enterprising behavior. Researchers [77] examined the enterprising behavior of 370 undergraduate and graduate students in four different disciplines at two universities in Slovakia. The studies of $[50,78]$ investigated the relationship between entrepreneurial inclination of students and psychological characteristics. Authors [79] also conducted a study concerning individual attributes related to entrepreneurship with a sample of university students.

In terms of the entrepreneurial process, the sample may be considered in the early stages and yet still capable of displaying personality and the psychological traits associated with entrepreneurs [47].

\subsection{Instrumentation}

There are two instruments used for this study. For the examination of enterprising behaviors, the Bolton Thompson Entrepreneurial Indicator (BTEI) was used, which is based upon the FACETS framework [28]. The FACETS framework divides the characteristics associated with intrapreneurialism into Focus, Advantage, Creativity, Ego-Inner and outer, Teamwork and Social (see also Table 1). This instrument has been used as a means of identifying intrapreneurs in large organizations [28]; [11] and the BTEI was developed specifically to measure entrepreneurial potential [52]. The BTEI contains thirty items for assessing the subject's entrepreneurial capacity, i.e., their potential for enterprising behavior, based upon the characteristics displayed.

For the assessment of preferred organizational culture, the Organizational Culture Assessment Instrument (OCAI) developed by [80] was used and is based upon the competing values framework (CVF). In this framework, organizational culture is not characterized as being a single type, but rather a combination of four types: clan; hierarchy; market; and adhocracy. Through this model, organizational culture can be seen as having one or possibly more dominant types or a culture where all four types are balanced, whilst all four types exist within an organization's culture.

\subsection{Analysis}

In studies such as [81], concerns arise when using an instrument measuring entrepreneurial traits that has been developed and used primarily in Western countries. To ensure a valid and reliable measure for entrepreneurship traits (ET) for university students in a transition economy such as Hungary, a principal component factor analysis was conducted on the enterprising characteristics with varimax rotation (see also [82]). The Kaiser-Meyer-Olkin (KMO), Bartlett and Total Variance Explained (TVE) tests were used for ascertaining sampling adequacy. From the resulting rotated component matrix, the groupings of components were assigned labels.

A linear regression analysis was conducted of culture types against components as used in other studies of culture and entrepreneurship, such as: [83-86]. 


\section{Results}

The OCAI uses an ipsative scale and any responses that did not sum to the specific total were deleted from the sample. This resulted in a final sample of 1056 students from a university, all studying in business fields. The sampling criteria applied was an active full-time university student in one of the business majors, without any gender or age limitations, and with no work experience. The respondents attended first and second year of bachelor (undergraduate) level. The respondents were acquired using a convenience sampling technique.

For the first phase of analysis, a rotated component matrix was produced as the key output of principal components analysis. These findings can be found in Table 3 .

Table 3. Rotated component matrix of Entrepreneurial characteristics.

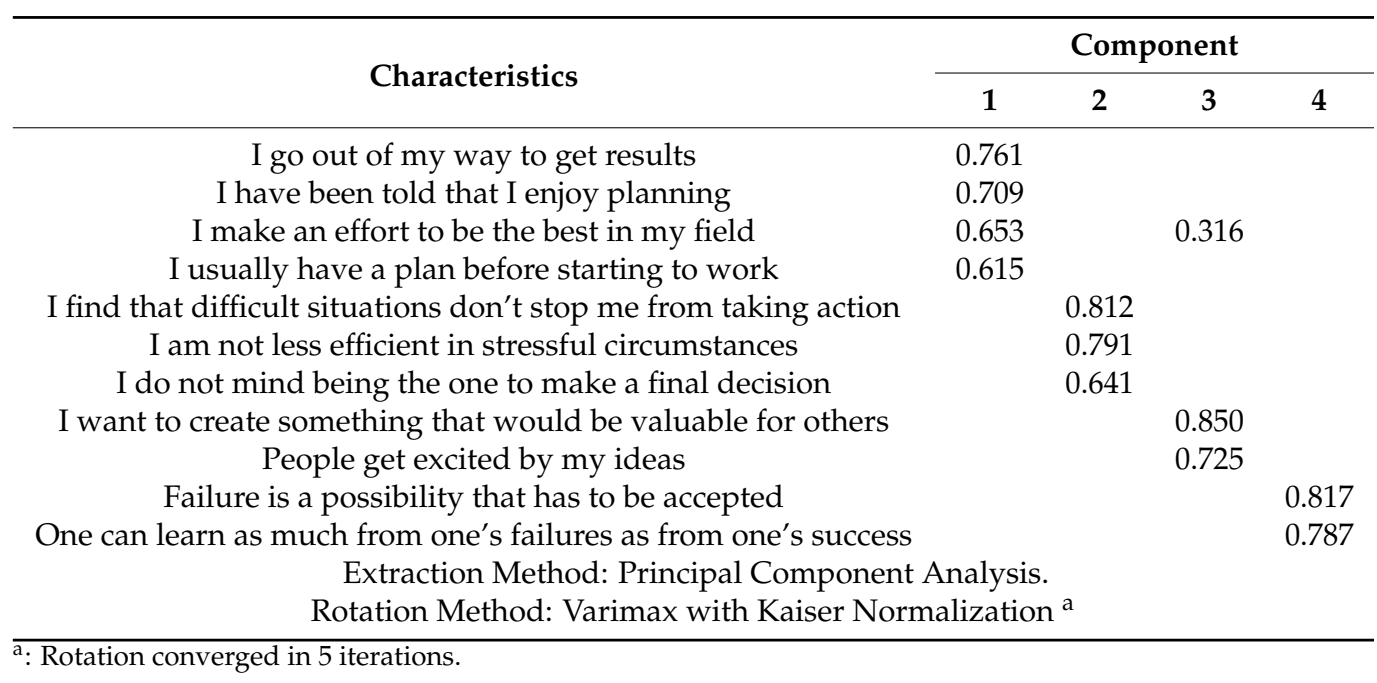

Using the results of Table 4, sample adequacy was tested. KMO was 0.678, Bartlett $\chi^{2}=1672,938$ with $p=0.000$; and TVE $=60.100 \%$. The interpretation of these groupings involved the detection of key themes (labels) according to the enterprising characteristics that were given and a typology of what those characteristics may be associated with, as a means of understanding the basis for these groupings. The labels can be seen in the following table (Table 4).

Table 4. Groupings of entrepreneurial characteristics.

\begin{tabular}{|c|c|c|c|}
\hline Component & Characteristics & Key Theme (Label) & Typology \\
\hline 1 & $\begin{array}{l}\text { I go out of my way to get results } \\
\text { I have been told that I enjoy planning } \\
\text { I make an effort to be the best in my field } \\
\text { I usually have a plan before starting to work }\end{array}$ & Planning on results & Project Manager \\
\hline 2 & $\begin{array}{l}\text { I find that difficult situations don't stop me from taking action } \\
\text { I am not less efficient in stressful circumstances } \\
\text { I do not mind being the one to make a final decision }\end{array}$ & Bearing the burden & Pressure Bearer \\
\hline 3 & $\begin{array}{l}\text { I want to create something that would be valuable for others } \\
\text { People get excited by my ideas }\end{array}$ & Innovating for others & Innovating Showstopper \\
\hline 4 & $\begin{array}{l}\text { Failure is a possibility that has to be accepted } \\
\text { One can learn as much from one's failures as from one's success }\end{array}$ & Learning from mistakes & Experimental Learner \\
\hline
\end{tabular}

In the final phase of the analysis, linear regression models were built of culture types against components (enterprising characteristics). Certain components in the sample were found to have direct or inverse relationship to values associated with one of the culture types. As shown in Figure 1, the Clan culture type is excluded as no significant relationships were found between the components and the clan culture type. 


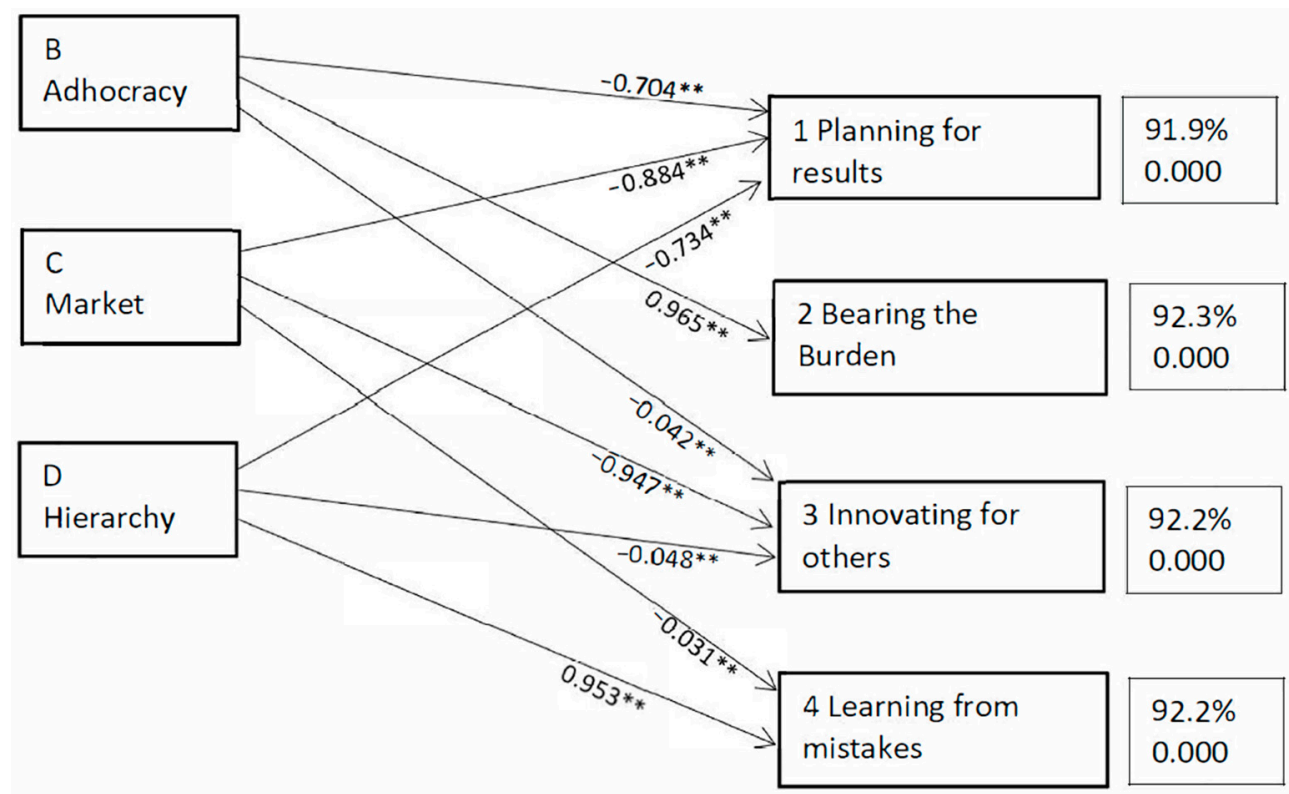

Figure 1. Linear regression model of entrepreneurial groupings (components) and preferred culture type (excluding clan type).

The significant connections are shown in the figure, denoted with arrows from the culture type to each of the four components. To the right of each of the components are the R-squares (determinant coefficients) shown as a percentage and in each case are high. To the right of the R-squares is the F-test's p, which is lower than $0.05(0.000)$ for all four components.

\section{Discussion}

The discussion section has been split into two areas. The first is concerns the relationship between enterprising behaviors and organizational culture types from the study, and the second section concerns the findings in relation to open innovation culture.

\subsection{Discussion: Intrapreneurial Fit, and Organizational Culture}

The four components that emerged from the empirical data in a principal component analysis and their consequent relationship with culture types as a result of the regression analysis are aimed at answering the research question of this explorative study, 'what is the relationship between enterprising characteristics and culture type?', as a means of uncovering the fit or misfit of enterprising employees and intrapreneurs with existing organizational culture types.

As the literature presented a range of sets of entrepreneurial characteristics, we conducted a principal components exploratory factor analysis (see Table 3) and revealed four component groupings that were labelled according to the characteristics within each component. The groupings were also ascribed roles relating to potential employees with enterprising behavior: Project Manager; Pressure Bearer; Innovating Showstopper; and Experimental Learner. These findings can be seen as an extension of the list of roles found in the original study using this instrument by Bolton and Thompson [52], such as Networker, Opportunity-spotter, and Project Champion (p. 5).

Following this, the relationship between culture types and the four components of enterprising behavior was investigated and the summary of these findings is shown in Table 5. 
Table 5. Summary of direction of relationships between culture types and components.

\begin{tabular}{ccccc}
\hline & \multicolumn{3}{c}{ Components } \\
\cline { 2 - 5 } Culture Type & $\mathbf{1}$ & $\mathbf{2}$ & $\mathbf{3}$ & $\mathbf{4}$ \\
& Planning on Results & Bearing the Burden & Innovating for Others & Learning from Mistakes \\
\hline Clan & none & none & none & none \\
\hline Adhocracy & inverse & direct & inverse & none \\
\hline Market & inverse & none & inverse & direct \\
\hline Hierarchy & inverse & none & inverse & dirse
\end{tabular}

Taken together, these results suggest that certain enterprising behaviors have significant direct or inverse relationships with culture types. There were no significant differences found for any of the four enterprising behaviors with the clan culture type. The clan type is very much inward-looking and focused on teams and doing things together. This would relate to the Team $(\mathrm{T})$ part of the FACETs framework. However, the team element of enterprising behavior did not emerge in the principal component analysis of our sample. The focus on human development and roles such as a mentor or coach was found in the literature (e.g., [58]). However, this depends on the entrepreneur's stage in the "entrepreneurial process" - Rather than take on the role of a coach or mentor, an entrepreneur may seek the help of mentors and coaches in the early days of starting up a business due to challenges such as the liability of newness. This is reflected in the focus of empirical studies, e.g., [87]. Although entrepreneurs may adopt coaching and mentoring roles in later years, e.g., [88], the respondents in this sample are in the early stages of the "entrepreneurial process", i.e., in the early stages of development as an entrepreneur/intrapreneur.

If we turn our focus towards the enterprising characteristics, we can see that those respondents that had the "planning on results" behavior had inverse relationships with values relating to the adhocracy, market and hierarchy cultures. This inverse relationship with the adhocracy type is explained by the creative, dynamic and experimental approaches of the adhocracy type that require more flexibility and discretion. The inverse relationship with the market culture may be explained under the saying 'a goal without a plan is just a wish'. These respondents highlight planning for results, whereas the market culture is focused upon competition, reputation and success. There is a competitive element to the "planning on results" grouping, which indicates the need for further research to confirm if the strength of values relating to planning in the market culture. The inverse relationship with the hierarchy culture is explained through the value placed on procedures and smooth functioning rather than specific outcomes. Thus, the long-term goals are characteristically task-focused stability and efficiency, as well as the smooth execution of tasks.

The enterprising characteristic of "bearing the burden" (bearing difficult decisions and stress) directly relates to the values of the adhocracy culture. The adhocracy culture values risk-taking, being experimental, innovating, freedom and showing initiative and freedom. Thus, the adhocracy culture places autonomy on the individual and this explains the relationship in our findings.

"Innovating for others" was found as a mix of two aspects: creativity, but within the context of its appreciation by others. There are inverse relationships with adhocracy, market and hierarchy cultures. This is most surprising in the case of the adhocracy as this is also focused upon innovation. However, the inverse relationship is explained within the context of the national culture. Hungary has a highly individualist culture compared to the majority of countries around the world [89], and, as such, individuals are expected to take care of themselves and their immediate families only. Although it wasn't raised in the piloting of the questionnaire or in previous studies using the BTEI in individualist national cultures (e.g., [90]), there is a need for further research into whether individualism countries score lower on the BTEI scale for these elements due to the focus on doing something for 
the sake of others, rather than for oneself. This finding also highlights the current debate on the effect of individualism on entrepreneurship [91,92].

For the enterprising characteristic "learning from mistakes", there is an inverse relationship with the market culture and a direct relationship with the hierarchy culture Learning from mistakes is an important aspect of ensuring that stability, efficiency and smooth running of the enterprise are maximized and this it seems that increased learning from mistakes is a necessity, especially bearing in mind the value placed on rules and procedures for this culture type. The inverse relationship with the market culture is indicative that the process of reflection required to learn from mistakes is averse to values of the market culture such as 'results-right-now', making fast decisions and moving fast in a competitive environment.

The need for alignment was found in the literature as requiring congruity between managerial practice and the culture (see $[63,71]$ ). The findings of this study confirm this congruity in the form of management being aware of how the culture may adversely affect enterprising behavior of existing and new employees, and tailoring performance expectations of intrapreneurs to fit the behaviors conducive to culture type.

These findings confirm existing literature in how a culture "misfit" has been found to inhibit entrepreneurial activities [72]. However, the previous study was conducted on a national culture level, and this study puts forward that this is also the case on an organizational culture level with regard to specific entrepreneurial behaviors.

\subsection{Discussion: Intrapreneurial Fit, and Open Innovation Culture}

The findings of this study raise important questions for open innovation dynamics from a cultural perspective. In their conceptual framework of a culture for open innovation dynamics, [93] suggest that intrapreneurs themselves have the potential to change organizational culture through a combination of symbols and language usage with legitimacy. Thus, whilst some enterprising behaviors were found in this study to "misfit" certain culture types, further research may extend the findings of our study and examine not only how organizational culture may encourage or limit enterprising behaviors, but also the effect of intrapreneurial behaviors on organizational cultures and which behaviors may push towards open innovation cultures, such as "innovating for others".

The Competing Values Framework [80] used in this study has been applied to the investigation of open innovation cultures, with a particular focus on how companies collaborate with one another when faced with increasing environmental complexity and dynamics. The authors [94] found a link between open foresight and the clan and adhocracy culture types, and yet no relationship was found with the market culture, despite being an externally focused culture. This confirms our findings of anomalies within the Competing Values Framework when considered in the context of an Open Innovation Culture, despite the CVF being a well validated and widely used model. The clan culture is the only culture type characterized by collaboration but has no external focus. Likewise, the adhocracy type is externally focused and values creativity, which are conducive to an Open Innovation Culture but does not necessarily value collaboration. The market culture places value on competition, playing to win and making fast decisions, rather than collaboration, despite being externally focused. In this way, two key elements of an open innovation culture, collaboration and openness to external know-how, seem incompatible in a single culture type. This would also explain how the market culture was not found to be related to open foresight in [94]'s (219) study and our findings that "innovating for others" has an inverse relationship to the adhocracy culture, due to "doing something for others" being best suited to a collaborative clan type and innovation best suited to the externally focused and creative adhocracy type (see previous section).

Besides collaboration, the clan culture also values openness [80] (but with an internal focus), which is also a key part of an open innovation culture [95], and the lack of significant findings with regard to the clan culture in our study may well be due to the mediating effect of national culture, as discussed in the previous section, combined with a lack of support 
for innovation impacting upon openness [96] with regard to Hungary [97]. Additionally, these findings highlight the important cultural distinction between openness to those inside and those outside the organization, both on a national and organizational level.

In closing, the findings indicate a need for organizations promoting an open innovation culture to adopt a multi-culturalist approach on an organizational level, i.e., the acceptance of a number of different organizational culture types existing in the organization, rather than aiming for alignment of all employees towards a single culture type. According to our findings, a multi-culturalist approach would also need to consider which combination of culture types would encourage or discourage the enterprising behaviors most desired by management.

\section{Conclusions and Implications}

This study aimed to investigate how a preferred organizational culture is linked to enterprising behavior, as a means of predicting intrapreneurial fit in organizations and determining which characteristics are conducive to certain culture types, and not others. This addresses the apparent lack of research into potential intrapreneurial fit (or misfit) and the link between culture and enterprising behaviors on an individual level, and, to achieve this, two instruments were used that have been validated in other studies, but not in this context and not in an investigation into possible relationships between the variables of each instrument.

An additional finding of this study is to build on existing empirical findings regarding the roles relating to enterprising behaviors with the addition of Project Manager, Pressure Bearer, Innovating Showstopper and Experimental Learner. Whilst these roles are well known in practice, such as the need for intrapreneurs to manage projects and work under the pressure of being the innovators for the organization in challenging times, empirical evidence has been limited in this respect. In this way, the findings also extend the original study upon which the FACETS instrument was developed and associated entrepreneurial roles suggested.

The results lead us to conclude that a number of enterprising behaviors, grouped according to principal components, are directly impacted by certain culture types. This result corroborates studies found in the literature indicating a link between the internal environment, such as organizational culture, and enterprising behaviors. It should be noted that whilst adhocracy, hierarchy and market culture types all stood out as catalysts of enterprising behaviors, the clan culture type had neither negative nor positive significant impacts upon enterprising behaviors. Likewise, the entrepreneurial grouping of 'Bearing the Burden' was found to be the least affected by culture types, relative to the other groupings. The lack of significant findings in these two elements indicate the further need for further work in this area, especially international collaborative research to further understand the role of national cultures, in how organizational culture preferences may inhibit or encourage enterprising behaviors. Moreover, the finding that certain cultures appear to act as "barriers" to enterprising behaviors due to this inverse relationship may indicate that the management expectations of intrapreneur performance should bear in mind how conducive their organization's culture is to the specific entrepreneurial behaviors expected.

Cultural change of any organizational is a challenging and costly process and although studies indicate the need for building entrepreneurial culture to encourage entrepreneurial behaviors, this is not always an option. Thus, they need to manage around the culture and the findings of this study allow HR managers to understand how a dominant culture type can encourage or discourage specific enterprising behaviors. The strong organizational culture promotes innovation and development regardless of the type of culture [98], so it is particularly useful to develop similar competencies of organizational members in the future. Moreover, during recruitment and selection stages, needs for certain enterprising behaviors will require the job advertisement in particular to be tailored towards a certain culture type (i.e., a certain set of values), and a reconsideration of the employer brand in general. However, before any changes are considered the organization will not only 
need to consider which enterprising behaviors are specifically required, but also undertake an audit of the organizational culture, as analyzing current and preferred cultures makes it possible to develop and implement strategies to move an organization in the desired direction [99], and then consider the impact of the culture on enterprising behaviors.

Innovation appears in all types of organizations and organizational cultures, and the required competencies are not exclusive in each organizational culture. Anna Lewandowska et al. [100] also defines the characteristic criteria of innovation; however, they cannot be assigned exclusively to any of the dimensions of organizational culture. At the same time, targeted skills development helps organizations to perform even better in addition to the capabilities they already have [101].

\section{Limitations and Future Research Directions}

For researchers and academics, this study raises the question of whether the entrepreneur or intrapreneur should be considered as a "whole package" or whether certain behaviors fit, or don't fit, certain cultures. The link between culture and enterprising behaviors in this study is a strong one, statistically speaking, but studies of similar sample size in other countries would serve to consolidate these findings and consider future directions for research, especially as the literature indicated that national culture plays an influential role on entrepreneurial behaviors. Furthermore, although much has been written about the need to develop "entrepreneurial cultures", not all companies have the resources to bring about cultural change. These companies should also be considered for further research into the practical and theoretical implications and how an existing culture can be managed in order to ensure intrapreneurs can function-and function well-within their internal setting.

The choice of sample was made on the basis of not having values corrupted through time spent in a particular organizational culture. However, there are studies indicating a potential impact of higher education on entrepreneurialism. Some researchers argue that formal education can lead to reduced curiosity and vision, as well as an increase in risk aversion [102,103]. Andrew Henley [104] longitudinal research found that educational background is not strongly associated with entrepreneurial aspirations and [105] argues that universities and business schools in particular should revise their curricula to stimulate innovative and critical thinking. Johnson PS et al. [106] called for discipline-based research into the effects of higher education on entrepreneurship.

Author Contributions: Conceptualization, N.C., Z.K.; methodology, N.C., Z.K.; validation, N.C., Z.K.; formal analysis, N.C., Z.K.; investigation, N.C., Z.K.; writing-original draft preparation, N.C.; writing-review and editing, Z.K.; visualization, N.C., Z.K. All authors have read and agreed to the published version of the manuscript.

Funding: This research received no external funding.

Institutional Review Board Statement: Not applicable.

Informed Consent Statement: Informed consent was obtained from all subjects involved in the study.

Data Availability Statement: Data is available on request.

Conflicts of Interest: The authors declare no conflict of interest.

\section{References}

1. Valsania, S.; Moriano, J.; Molero, F. Authentic leadership and intrapreneurial behavior: Cross-level analysis of the mediator effect of organizational identification and empowerment. Int. Entrep. Manag. J. 2016, 12, 131-152. [CrossRef]

2. Lages, M.; Marques, C.; Ferreira, J. Intrapreneurship and firm entrepreneurial orientation: Insights from the health care service industry. Int. Entrep. Manag. J. 2017, 13, 837-854. [CrossRef]

3. Kuratko, D.; Hornsby, J.; Covin, J. Diagnosing a firm's internal environment for corporate entrepreneurship. Bus. Horiz. 2014, 57, 37-47. [CrossRef]

4. Hisrich, R.D. Entrepreneurship/intrapreneurship. Am. Psychol. 1990, 45, 209-222. [CrossRef]

5. Salama, A. Creating and Re-Creating Corporate Entrepreneurial Culture; Routledge: London, UK, 2016. 
6. O'Reilly, C.A.; Chatman, J.A.; Caldwell, D.F. People and organizational culture: A profile comparison approach to assessing person-organization fit. Acad. Manag. J. 1991, 34, 487-516.

7. Vandenberghe, C. Organizational culture, person-culture fit, and turnover: A replication in the health care industry. J. Organ. Behav. 1999, 20, 175-184. [CrossRef]

8. Zhang, Z.; Yan, H.; Qi, J. What Do Chinese Entrepreneurs Think about Entrepreneurship: A Case Study of Popular Essays on Zhisland. J. Open Innov. Technol. Mark. Complex. 2020, 6, 86. [CrossRef]

9. Neessen, P.C.; Caniëls, M.C.; Vos, B.; de Jong, J.P. The Intrapreneurial Employee: Toward an Integrated Model of Intrapreneurship and Research Agenda. Int. Entrep. Manag. J. 2018, 15, 545-571. [CrossRef]

10. Bowen, D.E. The changing role of employees in service theory and practice: An interdisciplinary view. Human Resour. Manag. Rev. 2016, 26, 4-13. [CrossRef]

11. Kontor, M.F. The effects of person-organization fit and employee commitment. The mediating role of organizational culture. Arch. Bus. Res. 2019, 7, 121-131. [CrossRef]

12. Thompson, J.; Heinonen, J.; Scott, J.M. Innovation, Change and the Intrapreneurial Mindset. In Workforce Development: Strategies and Practices; Short, T., Harris, R., Eds.; Springer Science + Business Media Singapore: Singapore, 2014; pp. $263-277$.

13. Rigtering, J.P.C.; Weitzel, U. Work context and employee behavior as antecedents for intrapreneurship. Int. Entrep. Manag. J. 2013, 9, 337-360. [CrossRef]

14. Farrukh, M.; Khan, A.A.; Khan, M.S.; Ramzani, S.R.; Soladoye, B.S.A. Entrepreneurial intentions: The role of family factors, personality traits and self-efficacy. World J. Entrep. Manag. Sustain. Dev. 2017, 13, 303-317. [CrossRef]

15. George, G.; Zahra, S.A. Culture and its consequences for entrepreneurship. Entrep. Theory Pract. 2002, 26, 5-8. [CrossRef]

16. Stuetzer, M.; Audretsch, D.; Obschonka, M.; Gosling, S.; Rentfrow, P.; Potter, J. Entrepreneurship culture, knowledge spillovers and the growth of regions. Reg. Stud. 2018, 52, 608-618. [CrossRef]

17. Fritsch, M.; Obschonka, M.; Wyrwich, M. Historical roots of entrepreneurship-facilitating culture and innovation activity: An analysis for German regions. Reg. Stud. 2019, 53, 1296-1307. [CrossRef]

18. Hechavarria, D.M.; Reynolds, P.D. Cultural norms \& business start-ups: The impact of national values on opportunity and necessity entrepreneurs. J. Int. Entrep. Manag. 2009, 5, 417.

19. Fayolle, A.; Ulijn, J.M.; Degeorge, J.M. The entrepreneurial and innovative orientation of french, german and dutch engineers: The proposal of a European context based upon some empirical evidence from two studies. In Entrepreneurship Research in Europe: Outcomes and Perspectives; Fayolle, A., Kyrö, P., Ulijn, J.M., Eds.; Edward Elgar: Cheltenham, UK, 2005; pp. 227-255.

20. Lee, S.; Lim, S.; Pathak, R. Culture and entrepreneurial orientation: A multi-country study. Int. Entrep. Manag. J. 2009, 7, 1-15. [CrossRef]

21. Stokes, D.; Wilson, N.; Mador, M. Entrepreneurship; Cengage: Hampshire, UK, 2010.

22. Hirsch, R.D.; Peters, M.P. Entrepreneurship: Starting, Developing and Managing a New Enterprise; Irwin: Illinois, IL, USA, 1989.

23. Wennekers, S.; van Wennekers, A.; Thurik, R.; Reynolds, P. Nascent entrepreneurship and the level of economic development. Small Bus. Econ. 2005, 24, 293-309. [CrossRef]

24. Herron, L.; Robinson, R.B., Jr. A structural model of the effects of entrepreneurial characteristics on venture performance. J. Bus. Ventur. 1993, 8, 281-294. [CrossRef]

25. Bolton, B.; Thompson, J. Entrepreneurs, Talent, Temperament, Technique; Butterworth Heinemann: Oxford, UK, $2000 ;$ p. 5.

26. Eniola, A.A. The Entrepreneur Motivation and Financing Sources. J. Open Innov. Technol. Mark. Complex. 2021, 7, 25. [CrossRef]

27. Mousa, M.; Sági, J.; Zéman, Z. Brand and Firm Value: Evidence from Arab Emerging Markets. Economies 2021, 9, 5. [CrossRef]

28. Thompson, J. The facets of the entrepreneur: Identifying entrepreneurial potential. Manag. Decis. 2004, 42, 243-258. [CrossRef]

29. Veciana, J.; Aponte, M.; Urbano, D. University students' attitudes towards entrepreneurship: A two countries comparison. Int. Entrep. Manag. J. 2005, 1, 165-182. [CrossRef]

30. Sholl, J. Ten Principles of Intrapreneuring. Exec. Excell. 1998, 151, 17-18.

31. Sarasvathy, S.D.; Venkataraman, S. Entrepreneurship as method: Open questions for an entrepreneurial future. Entrep. Theory Pract. 2011, 35, 113-135. [CrossRef]

32. Krueger, N. What lies beneath? The experiential essence of entrepreneurial thinking. Entrep. Theory Pract. 2007, 31, 123-138. [CrossRef]

33. Knight, F.H. Risk, Uncertainty and Profit. In Hart, Schaffner, and Marx Prize Essays; Houghton Mifflin: Boston, MA, USA; New York, NY, USA, 1921; Volume 31.

34. Schumpeter, J. The Theory of Economic Development; Harvard University Press: Cambridge, UK, 1934.

35. Hayek, F. The Pure Theory of Capital; University Press: Chicago, IL, USA, 1941.

36. McClelland, D.C.; Atkinson, J.W.; Clark, R.A.; Lowell, L. The Achievement Motive; Appleton-Century-Crofts: New York, NY, USA, 1953.

37. Gaile, A.; Baumane-Vitolina, I.; Sumilo, E.; Skiltere, D.; Flores, R. Values and career behaviors of entrepreneurs and employees. Int. J. Entrep. Behav. Res. 2019, 26, 1607-1625. [CrossRef]

38. Kobia, M.; Sikalieh, D. Towards a search for the meaning of entrepreneurship. J. Eur. Ind. Train. 2010, 34, 110-127. [CrossRef]

39. Eysenck, M.W. Trait anxiety, repressors and cognitive biases. In Cognition, Emotion and Psychopathology: Theoretical, Empirical and Clinical Directions; Yiend, J., Ed.; Cambridge University Press: Cambridge, UK, 2004.

40. Rokeach, M. The Nature of Human Values; The Free Press: New York, NY, USA, 1973. 
41. Bednar, J.; Page, S.; Bramson, A.; Jones-Rooy, A. Conformity, consistency, and cultural heterogeneity. In Proceedings of the Annual Meeting of the American Political Science Association Marriott, Loews Philadelphia, and the Pennsylvania Convention, Philadelphia, PA, USA, 31August-3 September 2006.

42. McClelland, D. The Achieving Society; Van Nostrand: Princeton, NJ, USA, 1961.

43. Wales, W.; Monsen, E.; McKelvie, A. The organizational pervasiveness of entrepreneurial orientation. Entrep. Theory Pract. 2011, 35, 895-923. [CrossRef]

44. Dickson, P.; Weaver, K. The role of the institutional environment in determining firm orientation towards entrepreneurial behavior. Int. Entrep. Manag. J. 2008, 4, 467-483. [CrossRef]

45. Miller, D. The correlates of entrepreneurship in three types of firm. Manag. Sci. 1983, 29, 770-791. [CrossRef]

46. Covin, J.; Slevin, D. Implementing strategic missions: Effective strategic, structural and tactical choices. J. Manag. Stud. 1994, 31, 481-505. [CrossRef]

47. Canina, L.; Palacios, D.; Devece, C. Management theories linking individual and organizational level analysis in entrepreneurship research. Int. Entrep. Manag. J. 2012, 8, 271-284. [CrossRef]

48. Kraus, S.; Breier, M.; Jones, P.; Hughes, M. Individual entrepreneurial orientation and intrapreneurship in the public sector. Int. Entrep. Manag. J. 2019, 15, 1247-1268. [CrossRef]

49. Timmons, J.A.; Smollen, J.E.; Dingee, A.L.M. New Venture Creation; Irwin: Homewood, CA, USA, 1977.

50. Koh, H.C. Testing hypotheses of entrepreneurial characteristics: A study of Hong Kong MBA students. J. Manag. Psychol. 1996, $11,12-25$.

51. Littunen, H. Entrepreneurship and the characteristics of the entrepreneurial personality. Int. J. Entrep. Behav. 2000, 6, 295-309. [CrossRef]

52. Bolton, B.; Thompson, J. Entrepreneurs: Talent, Temperament, Technique; Elsevier: Boston, MA, USA, 2004.

53. Timmons, J.A.; Spinelli, S. New Venture Creation: Entrepreneurship for the 21st Century; McGraw-Hill/Irwin: New York, NY, USA, 2004.

54. Gürol, Y.; Atsan, N. Entrepreneurial characteristics amongst university students. Educ. Train. 2006, 48, 25-38. [CrossRef]

55. Rauch, A.; Frese, M. Let's put the person back into entrepreneurship research: A meta-analysis on the relationship between business owners' personality traits, business creation, and success. Eur. J. Work Organ. Psychol. 2007, 16, 353-385. [CrossRef]

56. Kuratko, D.F. The entrepreneurial imperative of the 21st century. Bus. Horiz. 2009, 52, 421-428. [CrossRef]

57. Farrington, S.M.; Louw, M.J.; Venter, D.J.L. Entrepreneurial intentions: Demographic perspectives of South African business students. S. Afr. J. Bus. Manag. 2012, 43, 41-49. [CrossRef]

58. Kyrgidou, L.; Spyropoulou, S. Drivers and Performance Outcomes of Innovativeness: An Empirical Study. Br. J. Manag. 2013, 24, 281-298. [CrossRef]

59. Alshanty, A.M.; Emeagwali, O.L. Market-sensing capability, knowledge creation and innovation: The moderating role of entrepreneurial-orientation. J. Innov. Knowl. 2019, 4, 171-178. [CrossRef]

60. Monteiro, A.P.; Soares, A.M.; Rua, O.L. Linking intangible resources and entrepreneurial orientation to export performance: The mediating effect of dynamic capabilities. J. Innov. Knowl. 2019, 4, 179-187. [CrossRef]

61. Schein, E. Organizational culture. Am. Psychol. 1990, 45, 109-119. [CrossRef]

62. Dobni, C.B. Measuring innovation culture in organizations: The development of a generalized innovation culture construct using exploratory factor analysis. Eur. J. Innov. Manag. 2008, 11, 539-559. [CrossRef]

63. Hayton, J.C.; Zahra, G.G.; Zahra, S.A. National culture and entrepreneurship: A review of behavioral research. Entrep. Theory Pract. 2002, 26, 33-52. [CrossRef]

64. Atuahene-Gima, K.; Ko, A. An empirical investigation of the effect of market orientation and entrepreneurship orientation alignment on product innovation. Organ. Sci. 2001, 12, 54-74. [CrossRef]

65. Pothukuchi, V.; Damanpour, F.; Choi, J.; Chao, C.; Seung, H. National and Organizational Culture Differences and International Joint Venture Performance. J. Int. Bus. Stud. 2002, 33, 243-265. [CrossRef]

66. Mueller, S.L.; Thomas, A.S. Culture and entrepreneurial potential: A nine country study of locus of control and innovativeness. J. Bus. Ventur. 2001, 16, 51-55. [CrossRef]

67. Eesley, D.T.; Longenecker, C.O. Gateways to Intrapreneurship. Ind. Manag. 2006, 48, 18-23.

68. Aloulou, W.; Fayolle, A. A Conceptual Approach of the Entrepreneurial Orientation within the Small Business Context. J. Enterprising Cult. 2005, 13, 21-45. [CrossRef]

69. Ling, Y.; López-Fernández, M.C.; Serrano-Bedia, A.M.; Kellermans, F.W. Organizational culture and entrepreneurial orientation: Examination through a new conceptualization lens. Int. Entrep. Manag. J. 2020, 16, 709-737. [CrossRef]

70. Shane, S. Why do some countries invent more than others? J. Bus. Ventur. 1992, 7, 29-46. [CrossRef]

71. Hofstede, G. Cultures and Organizations, Software of the Mind; McGraw-Hill: London, UK, 1991.

72. Bachmann, J.; Engelen, A.; Schwens, C. Toward a Better Understanding of the Association Between Strategic Planning and Entrepreneurial Orientation-The Moderating Role of National Culture. J. Int. Manag. 2016, 22, 297-315. [CrossRef]

73. Hashimoto, M.; Nassif, V.M.J. Inhibition and encouragement of entrepreneurial behavior: Antecedents analysis from managers' perspectives. Braz. Adm. Rev. 2014, 11, 385-406. [CrossRef]

74. Morrison, A. Entrepreneurship: What triggers it? Int. J. Entrep. Behav. Res. 2000, 6, 59-71. [CrossRef] 
75. Comisón-Haba, S.; Clemente-Almendros, J.A.; Gonzalez-Cruz, T. How technology-based firms become also highly innovative firms? The role of knowledge, technological and managerial capabilities, and entrepreneurs' background. J. Innov. Knowl. 2019, 4, 162-170. [CrossRef]

76. Global Entrepreneurship Monitor. GEM Entrepreneurial Behavior and Attitudes. Available online: https://www.gemconsortium. org/economy-profiles/hungary-2 (accessed on 25 May 2016).

77. Holienka, M.; Holienková, J.; Gál, P. Entrepreneurial Characteristics of Students in Different Fields of Study: A View from Entrepreneurship Education Perspective. Acta Univ. Agric. Silvic. Mendel. Brun. 2015, 63, 1879-1889. [CrossRef]

78. Yusof, M.; Sandhu, M.S. Relationship between psychological characteristics and entrepreneurial inclination: A case study of students at University Tun Abdul Razak. J. Asia Entrep. Sustain. 2007, 3, $23-41$.

79. Pfeifer, S.; Šarlija, N.; Zekić sušac, M. Shaping the Entrepreneurial Mindset: Entrepreneurial Intentions of Business Students in Croatia. J. Small Bus. Manag. 2016, 54, 102-117. [CrossRef]

80. Cameron, K.S.; Quinn, R.E. Diagnosing and Changing Organizational Culture Based on the Competing Values Framework; AddisonWesley Publishing: Reading, MA, USA, 1999.

81. Daud, S.N.; Abdullah, M.; Hassan, N.A. Exploratory factor analysis of entrepreneurship traits among engineering students. Int. J. Entrep. 2019, 2, 39-50. [CrossRef]

82. Louw, L.; van Eeden, S.M.; Bosch, J.K.; Venter, D.J.L. Entrepreneurial traits of undergraduate students at selected South African tertiary institutions. Int. J. Entrep. Behav. Res. 2003, 9, 5-26. [CrossRef]

83. Urban, B. Entrepreneurship in the rainbow nation: Effect of cultural values and ESE on intentions. J. Dev. Entrep. 2006, 11, 171-186. [CrossRef]

84. Mai, Y.; Gan, Z. Entrepreneurial opportunities, capacities and entrepreneurial environments. Chin. Manag. Stud. 2007, 1, 216-224. [CrossRef]

85. Solesvik, M.; Westhead, P.; Matlay, H. Cultural factors and entrepreneurial intention. Educ. Train. 2014, 56, 680-696. [CrossRef]

86. Yao, X.; Wu, X.; Long, D. University students' entrepreneurial tendency in China. J. Entrep. Emerg. Econ. 2016, 8, 60-81. [CrossRef]

87. Mansoori, Y.; Karlsson, T.; Lundqvist, M. The influence of the lean startup methodology on entrepreneur-coach relationships in the context of a startup accelerator. Technovation 2019, 84, 37-47. [CrossRef]

88. Santini, S.; Baschiera, B.; Socci, M. Older adult entrepreneurs as mentors of young people neither in employment nor education and training (NEETs). Evidences from multi-country intergenerational learning program. Educ. Gerontol. 2020, 46, 1-20. [CrossRef]

89. Falkné Bánó, K. Identifying Hungarian Cultural Characteristics in Europe's Cultural Diversity in the 21st Century: A Controversial Issue. 2014. Available online: http:/ / publikaciotar.repozitorium.uni-bge.hu/209/1/12\%20Falkn\%C3\%A9.pdf (accessed on 12 January 2021).

90. Blackwell, A.J.; Coltman, T. Economic Gardening in Australia: Measuring attitudes towards growth. Aust. N. Z. Acad. Manag. Syd. 2007, 1-14. Available online: https://www.anzam.org/wp-content/uploads/pdf-manager/1806_COLTMANTIM_146.PDF (accessed on 12 January 2021).

91. Rantanen, T.; Toikko, T. The relationship between individualism and entrepreneurial intention-A Finnish perspective. J. Enterprising Communities People Places Glob. Econ. 2017, 11, 289-306. [CrossRef]

92. Pinillos, M.J.; Reyes, L. Relationship between individualist-collectivist culture and entrepreneurial activity: Evidence from Global Entrepreneurship Monitor data. Small Bus. Econ. 2011, 37, 23-37. [CrossRef]

93. Yun, J.J.; Zhao, X.; Jung, K.; Yigitcanlar, T. The Culture for Open Innovation Dynamics. Sustainability 2020, 12, 5076. [CrossRef]

94. Wiener, M.; Boer, H. Cultural prerequisites for participating in open foresight. R. D Manag. 2019, 49, 703-715. [CrossRef]

95. Yun, J.J.; Lee, M.; Park, K.; Zhao, X. Open Innovation and Serial Entrepreneurs. Sustainability 2019, 11, 5055. [CrossRef]

96. Dos Santos, L.L.; Pereira, R.M.; Borini, F.M.; Raziq, M.M.; Oliveira Junior, M.D.M. The influence of national culture and support to innovate on openness to innovation. Int. J. Entrep. Innov. Manag. 2020, 24, 189-209.

97. Hollanders, H.; Es-Sadki, N.; Merkelbach, I.; Khalilova, A. "European Innovation Scoreboard 2020", Report of the European Innovation Scoreboard Project; European Commission: Brussels, Belgium, 2020.

98. Vnoučková, L.; Urbancová, H. Setting Organizational Culture to Develop Potential and Innovativeness. Qual. Innov. Prosper. 2020, 24, 54-68. [CrossRef]

99. Shepstone, C.; Currie, L. Building our strengths: Working towards a preferred workplace culture. In Workplace Culture in Academic Libraries: The Early 21st Century; Blessinger, K., Hrycaj, P., Eds.; Chandos Publishing: Oxford, UK, 2013; pp. 21-37.

100. Lewandowska, A.; Stopa, M. The impact of innovative professional qualifications on the sense of employment security: Evidence from Poland. Econ. Sociol. 2020, 13, 72-83. [CrossRef]

101. Szymańska, K. Organizational culture as a part in the development of open innovation-the perspective of small and medium-sized enterprises. Management 2016, 20, 142-154. [CrossRef]

102. Fallows, J. The case against credentialism. Atl. Mon 1985, 256, $49-67$.

103. Shapero, A. Are Business Schools Teaching Business? Inc. 1980, 4, 13. Available online: https://www.inc.com/magazine/198201 01/7105.html (accessed on 12 January 2021).

104. Henley, A. From entrepreneurial aspiration to business start-up: Evidence from British longitudinal data. Swans. Univ. Sch. Bus. Econ. Work. Pap. 2005. [CrossRef] 
105. Kirby, D.A. Entrepreneurship education: Can business schools meet the challenge. In Proceedings of the 2005 San Francisco-Silicon Valley Global Entrepreneurship, San Francisco, CA, USA, 22-25 March 2006.

106. Johnson, P.S.; Simon, C.P.; Wijbenga, F. Nascent entrepreneurship research: Achievements and opportunities. Small Bus. Econ. 2006, 27, 1-4. [CrossRef] 